\title{
KALIMAT IMPERATIF DALAM NOVEL SELENA KARYA TERE LIYE (KAJIAN SINTAKSIS)
}

\author{
Sri Wulandari IAI Darussalam Blokagung Banyuwangi \\ sriwulandary296@gmail.com
}

\begin{abstract}
ABSTRAK
Novel sebagai salah satu bentuk karya sastra diharapkan dapat menghasilkan nilainilai positif bagi pembacanya, sehingga mereka bisa peka terhadap masalahmasalah yang berkaitan dengan kehidupan sosial dan mendorong untuk berperilaku yang baik. Novel biasanya menceritakan tentang gambaran-gambaran realita kehidupan manusia dengan lingkungan yang ada disekitarnya. Penelitian ini difokuskan pada wujud dan makna kalimat imperatif yang ada di novel selena karya Tere Liye.Tujuan penelitian ini adalah untuk mengetahui wujud dan makna kalimat imperatif dalam novel Selena karya Tere Liye.Penelitian ini menggunakan teknik analisis data Deskriptif Kualitatif. Pengumpulan data dilakukan dengan metode simak melalui teknik catat. Dari hasil penelitian menunjukan adanya kesimpulan dalam novel Selena karya Tere Liye yaitu menemukan wujud kalimat imperatif Intrasitif dan ditemukan 8 makna yaitu kalimat imperatif permohonan, dan kalimat imperatif permintaan, kalimat imperatif harapan, kalimat imperatif larangan, dan kalimat imperatif pembiaran, kalimat imperatif ajakan, kalimat impratif Imbauan.Dari paparan data dan temuan berjumlah 80 kalimat imperatif. Yang paling banyak ditemukan yaitu kalimat imperatif permohonan sebanyak 48 data, sedangkan yang paling sedikit adalah kalimat imperatif pembiaran sebanyak 2 data.
\end{abstract}

Kata Kunci: Kalimat Imperatif, Novel

\begin{abstract}
Novel as a form of literary work is expected to produce positive values for readers, so that they can be sensitive to problems related to social life and encourage good behavior. Novels usually tell about the realities of human life with the environment around them. This research focuses on the form and meaning of imperative sentences in Tere Liye's novel Selena. The purpose of this study was to determine the form and meaning of imperative sentences in Tere Liye's Selena novel. This study uses descriptive qualitative data analysis techniques. Data collection was done by observing method through note taking technique. The research results show that there are conclusions in the novel Selena by Tere Liye, namely finding the form of the imperative Intrasitive sentence and found 8 meanings, namely the imperative request sentence, and the imperative request sentence, the imperative expectation sentence, the imperative sentence for prohibition, and the imperative sentence for allowing, the imperative sentence for invitation, From the data and findings, there are 80 imperative sentences. The most common found were imperative sentences of request with as much as 48 data, while the least was the imperative sentences of leaving with 2 data.
\end{abstract}

Keywords: Imperative Sentences, Novel 


\section{A. Pendahuluan}

Bahasa merupakan peranan penting dalam kehidupan manusia. Bahasa diidentifikasikan sebagai komunikasi antar makhluk manusia yang dicirikan dan penggunaan simbol-simbol lisan atau tertulis secara acak sesuai makna yang telah diterima oleh masyarakat penutur. Dilihat dari segi fungsinya bahasa sebagai alat komunikasi, bahasa memang merupakan medium penting atau medium utama dalam komunikasi baik secara tulis maupun secara lisan. Pernyataan ini menyatakan bahwa fungsi bahasa adalah untuk berkomunikasi manusia baik tulis maupun lisan. Contohnya seperti pidato, orasi, ceramah, diskusi, dan lain sebagainya. Sedangkan ragam bahasa tulis adalah ragam bahasa yang digunakan manusia yang dihasilkan oleh alat tulis. Seperti, tabloid, majalah, buku cerita, buku motivasi, buku bergambar, koran, novel.

Menurut Abdul Chaer (2012 :240) Kalimat merupakan satuan yang langsung digunakan dalam berbahasa. Sedangkan menurut Bagus Putrayasa (2014: 20) kalimat merupakan konstruksi besar yang terdiri dari satu kata, dua kata, atau lebih. satuan Bahasa yang terdiri dari satu kata atau lebih yang mempunyai makna.

Salah satu kunci sukses dalam berkomunikasi dengan menggunakan bahasa adalah dengan ketetapan dan keteraturan bahasa. Ketetapan dan keteraturan berbahasa itu tentunya memerlukan sebuah pengetahuan dan pemahaman yang luas mengenai ilmu kebahasaan. Salah satu cabang ilmu yang mempelajari tentang seluk beluk bahasa adalah ilmu bahasa linguistik umum, yang berisi tentang cabang ilmu bahasa, diantaranya ilmu fonologi, morfologi, sintaksis, semantik, prakmatik, yang mana masing-masing bidang tersebut saling berkesinambungan. Pada ragam tulis, diperlukan kesempurnaan struktur kalimat supaya orang yang membacanya dapat memahami apa yang disampaikan. Dalam wujud tulisan berhuruf latin, kalimat dimulai dengan huruf kapital dan diakhiri dengan tanda titik (.), tanda tanya (?), tanda seru (!).

Sebaliknya, ragam lisan tidak menuntut kelengkapan unsur-unsur gramatikal karena sifatnya lebih kepada hubungan komunikasi. Hubungan seperti itu memerlukan mitra tutur sebagai lawan yang diajak bicara. Tanpa kelengkapan unsur gramatikal, pesan yang disampaikan dapat dipahami karena bahasanya dibantu oleh gesture atau 
gerak tubuh, mimik muka, dan intonasi sang penutur. Intonasi yang dimaksud disini adalah dengan suara naik turun, keras lembut, disela jeda dan diakhiri intonasi akhir yang diikuti oleh kesenyapan untuk mencegah terjadinya perpaduan bunyi atau proses fonologis lainnya. Jadi dalam menyampaikan suatu pesan atau dalam melakukan komunikasi, manusia mengungkapkan ide-idenya melalui kalimat-kalimat.

Salah satu jenis kalimat yang dipakai berkomunikasi dalam novel Selena karya Tere Liye adalah kalimat imperatif. Kalimat Imperatif dapat pula digunakan untuk menyebut bentuk kata kerja (verb form) yang digunakan dalam kalimat imperatif tersebut. Jika membicarakan tuturan imperatif (kalimat perintah) biasanya yang ada di dalam benak kita adalah tuturan yang menggunakan konstruksi imperatif atau perintah. Artinya, sudut pandang yang dipakai dalam kajian tuturan imperatif hanya berfokus pada aspek struktural. Padahal, pernyataan yang demikian dalam perkembangan pemakaian bahasa secara fungsional dapat menimbulkan persoalan. Persoalannya adalah bahwa dalam kegiatan bertutur makna imperatif ternyata tidak hanya dapat dinyatakan dengan konstruksi imperatif atau perintah saja melainkan dapat pula dinyatakan dengan konstruksi-konstruksi lainnya. Konstruksi lain yang dimaksud adalah konstruksi interogatif (pertanyaan) dan deklaratif (pernyataan).

Objek kajian dalam penelitian ini adalah novel Selena Karya Tere Liye yang merupakan novel terbitan 2020 diterbitkan pertama kali oleh Penerbit Gramedia Pustaka Utama. Novel Selena karya Tere Liye banyak menggunakan kalimat imperatif. Kalimat imperatif merupakan kalimat perintah yang mengandung maksud memerintah atau meminta agar mitra tutur melakukan sesuatu sebagaimana diinginkan si penutur. Penggunaan imperatif dalam novel Selena karya Tere Liye dapat di lihat dari bentukbentuk tuturan yang di tuturkan. Bentuk tuturan imperatif dalam novel ini merupakan salah satu bagian dari bentuk tuturan direktif, yaitu bentuk tuturan yang dimaksudkan penuturannya untuk membuat pengaruh agar si mitra tutur melakukan tindakan, misalnya, memesan (orderin), memerintah (commanding), memohon (requesting), menasehati (advising), dan merekomendasi (recommending). Di dalam imperatif itu terdapat bentuk-bentuk kesantunan yang jelas wujud, maksud tuturan dan konteks tutur yang dituturkan. 
Penelitian tentang masalah kalimat imperatif dalam novel selena karya tere liye ini adalah sebuah karya sastra itu merupakan hasil imajinasi kreatifitas dari seseorang pengarang yang dipengaruhi dari segi fisik maupun sosialnya yang dia tuangkan kedalam bentuk tulisan yang berbentuk karya sastra. Yang mana buku ini termasuk jenis sebuah karya sastra nonfiksi. Sastra nnfiksi merupakan merupakan sebuah karya sastra dari serang pengarang yang merupakan kajian keilmuan dan suatu pengalaman.

Salah satu bentuk penggunaan kalimat imperatif dalam novel Selena karya Tere Liye dapat dilihat dalam sebuah tuturan " menyingkir segera dari ruangan ini ! aku punya banyak pekerjaan penting selain mengurusi tiga mahasisiwa baru yang susah diatur! " ox berseru. Tuturan ini mengandung makna kalimat imperatif suruhan karena dalam tuturan tersebut terdapat maksud menyuruh untuk melakukan suatu tindakan yaitu, agar segera menyingkir dari ruangan tersebut. Penelitian kalimat imperatif dalam novel selena karya Tere Liye ini perlu diakukan karena terkadang banyak seseorang yang belum mengetahui tentang kalimat imperatif apa sajakah yang ada didalam novel selena karya Tere Liye.

\section{B. Landasan Teori}

a. Bahasa

Bahasa pada hakikatnya adalah bunyi yang dipergunakan oleh manusia sebagai saranakomunikasi. Bahasa dipandang secara umum sebagai sarana komunikasi yangkhas dan unik oleh penggunanya. Penggunaan suatu bahasa untuk berinteraksiantarwarganya apabila diperhatikan dengan seksama bahasa yang digunakan wargasatu dengan yang lain agak berbeda dengan bahasa yang dipergunakan oleh wargalainnya. Perbedaan bentuk penggunaan bahasa tersebut terdapat pada bunyi ataulafal, pilihan kata, bahkan pada struktur kalimatnya.

Menurut Kamu Linguistik edisi ke 4201124 bahasa adalah sistem lambang unyi yang digunakan oleh para anggota suatu masyarakat untuk bekerja sama, berinteraksi, dan mengidentifikasikan diri . Tuturan bahasa terdiri atas bunyi dan tidak sembarang bunyi saja, bunyi-bunyi tertentu, yang agak berbeda- beda menurut bahasa tertentu (Verhaar, 2010: 10). Wujud dari penggunaan bahasa yang menunjukkan perbedaan kecil maupun besar, berupa perbedaan- perbedaan satuan bunyi fonem 
sampai pada pengungkapan kalimatnya, itulah yang disebut variasi bahasa. Bahkan tidak ada satu bahasa yang tidak mempunyai variasi bahasa.

Dari beberapa pengertian pendapat di atas dapat disimpulkan bahwa bahasa merupakan sistem lambang bunyi yang digunakan oleh para anggota suatu masyarakat untuk bekerja sama, berinteraksi, bahasa juga menunjukkan perbedaan kecil maupun besar, berupa perbedaan- perbedaan satuan bunyi fonem sampai pada pengungkapan kalimatnya.

b. Novel

Nurgiyantoro (2010: 10) mengemukakan bahwa novel merupakan karya fiksi yang dibangun oleh unsur-unsur pembangun, yakni unsur intrinsik dan unsur ekstrinsik. Novel juga diartikan sebagai suatu karangan berbentuk prosa yang mengandung rangkaian cerita kehidupan seseorang dengan orang lain di sekelilingnya dengan menonjolkan watak dan sifat pelaku. Novel merupakan jenis karya sastra yang ditulis dalam bentuk naratif yang mengandung konflik tertentu dalam kisah kehidupan tokoh-tokoh dalam ceritanya.

Menurut Rostamaji dan Agus priantoro dalam jurnal psikologi Novel merupakan karya sastra yang mempunyai dua unsur, yaitu unsur intrinsik dan unsur ekstrinsik yang kedua saling berhubungan karena sangat berpengaruh dalam kehadiran sebuah karya sastra.

Dari beberapa pengertian pendapat di atas dapat disimpulkan bahwa novel adalah sebuaah karya sastra yang merupakan hasil imajinasi kreatifitas dari seorang pengarang yang dipengaruhi dari segi fisik maupun sosialnya yang dia tuangkan dalm bentuk tulisan yang berbentukkarya sastra yang mempunyai dua unsur yaitu intrinsik dan unsur ekstrinsik yang keduanya sangat berhubungan karena sangat berpengaruh dalam kehadiran sebuah karya sastra.

\section{c. Kalimat}

Menurut Abdul chaer (2012 : 240 kalimat merupakan satuan yang langsung digunakan dalam berbahasa, maka tatabahasawan tradisional biasanya membuat devinisi kalimat dengan mengaitkan peranan kalimat itu sebagai alat interaksi dan kelengkapan pesan atau isi yang akan disampaikan. 
Menurut abdul chaer 2015 : 44 kalimat adalah satuan sintaksis yang disusun dari konstituen dasar, yang biasanya berupa klausa, dilengkapi dengan konjungsi bila diperlukan, serta disertai dengan intonasi final. Dari beberapa pengertian pendapat di atas dapat disimpulkan bahwa kalimat adalah Kalimat adalah satuan bahasa terkecil, dalam wujud lisan atau tulisan, yang mengungkapkan pikiran yang utuh yang langsung digunakan dalam berbahasa yang memounyai satuan sintaksis yang disusun dari konstituen dasar, yang biasanya berupa klausa.

\section{d. Sintaksis}

Kata "sintaksis" berasal dari Yunani sun 'dengan' dan tattein 'menempatkan'. Istilah tersebut secara etimologis berarti: menempatkan bersama-sama kata-kata menjadi kelompok kata atau kalimat dan kelompok-kelompok kata menjadi kalimat. Abdul chaer (2012:222 ) mengatakan bahwa sintaksis adalah bidang dari tuturan linguistikyang secara tradisional tersebut tata Bahasa atau gramatika. Sedangkan menurut M. Ramlan 200518 mengatakan istilah sintaksis secara langsung terambil dari bahasa belanda syntaxis, dalam bahas inggris digunakan bahasa syntax, Sintaksis ialah bagian atau cabang dari ilmu bahasa yang membicarakan seluk beluk wacana kalimat, klausa, dan frase.

\section{e. Klausa}

Klausa merupakan tataran didalam sintaksis yang berada didalam tataran frase dan dibawah tataran kalimat.Dalam berbagai karya linguistik mungkin ada perbedaan konsep karena penggunaan teori analisis yang berbeda. Menuru Abdul Chaer dalam buku linguistik umum (2012 : 231) Klausa adalah satuan sintaksis berupa runtunan kata-kata berknstruksi predikatif. Artinya, didalam konstruksi itu ada komponenkomponen, berupa kata atau frase, yang berfungsi sebagai predikat dan yang lain berfungsi sebagai subjek, sebagai objek, dan sebagai keterangan. Dilihat dari jumlah dan jenisnya, klausa kalimat dibagi menjadi:

\section{(a). Kalimat Tunggal atau Ukara Lamba}

Kalimat tunggal adalah kalimat yang memiliki satu klausa bebas memiliki sedikitnya fungtor subjek dan predikat.Perhatikan contoh berikut. 
Ibu Mencuci dan Bapak membaca Koran.

Di dalam kalimat tersebut klausa ibu mencuci dan bapak membaca Koran disebut klausa utama atau klausa bebas, yaitu klausa yang potensial untuk menjadi kalimat tunggal yang mandiri.

\section{(b). Kalimat Majemuk}

Kalimat majemuk adalah kalimat yang memiliki lebih dari satu klausa bebas atau terdiri dari satu klausa bebas dan sekurang-kurangnya satu klausa terikat. Klausa bebas adalah klausa yang dapat berdiri sendiri seperti kalimat sempurna, dengan kata lain dapat dikatakan sebagai kalimat majemuk setara dan kalimat majemuk bertingkat.

Abdul chaer dalam buku sintaksis bahasa indonesia (2015 41) klausa merupakan satuan sintaksis yang berada dalam satuan frase dan dibawah satuan kalimat, berupa runtunan kata-kata berkonstruksi predilatif. Artinya di dalamkonstruksi itu ada komponen berupa kata atau frase, yang berfungsi sebagai predikat, dan yang lain berfungsi sebagai subjek, sebagai objek dan sebagainya. f. Wujud Tuturan

Wujud tuturan yaitu bentuk tuturan yang digunakan penutur untuk menyampaikan pesan kepada lawan tutur. Menurut Putrayasa (2011: 19) wujud tuturan berdasarkan modus (isi atau amanat) yang ingin disampaikan dibedakan menjadi tiga, yaitu kalimat berita, kalimat tanya, dan kalimat perintah. Penggolongan kalimat tersebut tidak berkaitan langsung dengan nilai komunikatifnya.Kalimat interogatif biasanya digunakan untuk bertanya atau meminta informasi, namun pada konteks tertentu dapat bermakna perintah (sejenis perintah halus).Keempat pembagian tersebut dieksplanasikan satu per satu di bawah ini.

\section{(a).Kalimat Berita (kalimat deklaratif)}

Kalimat berita dikenal dengan kalimat deklaratif. Kalimat deklaratif yaitu kalimat yang isinya menyatakan berita atau pernyataan untuk diketahui oleh orang lain (pendengar atau pembaca). Kalimat berita berfungsi memberitahukan sesuatu kepada orang lain. Menurut Wikibuku bahasa Indonesia Kalimat berita merupakan kalimat yang memberikan atau memaparkan sebuah kejadian/ peristiwa. Arti Kalimat berita adalah kalimat yang isinya mengungkapkan peristiwa atau kejadian. Anda dapat menggunakan intonasi untuk membedakan kalimat berita dengan kalimat lain. 
Ciricirinya adalah: Intonasi kalimat berita bersifat netral. Isinya berupa pemberitahuan.Bentuk kalimat berita dimulai dengan huruf besar, dan diakhiri dengan tanda titik Bentuk kalimat berita dapat dilihat pada contoh berikut.

Kamis pagi Bapak sama Ibu mau pergi ke Bandung.

(b). Kalimat Tanya (kalimat interogatif)

Kalimat tanya berfungsi untuk menanyakan sesuatu. Secara formal kalimat tanya ditandai oleh kehadiran kata tanya apa, bagaimana, kapan, dimana, siapa, mengapa, berapa, dan sebagainya sesuai dengan tujuan atas sesuatu yang ingin ditanyakan atau sebagai penegas. Bentuk kalimat interogatif biasanya digunakan untuk meminta jawaban "ya" atau "tidak", atau informasi mengenai sesuatu atau seseorang dari lawan bicara atau pembaca. Bentuk kalimat tanya dapat dilihat pada contoh berikut.

Pak guru bahasa Jawa yang baru itu namanya siapa?

(c). Kalimat Perintah (Kalimat Imperatif)

Pengertian kalimat perintah menurut Kamus Besar Bahasa Indonesia (KBBI) adalah kalimat yang mengandung intonasi dan makna perintah atau larangan.Jenisjenis kalimat perintah di antaranya adalah kalimat perintah ajakan, kalimat perintah larangan, kalimat perintah permohonan, kalimat perintah mengizinkan, kalimat perintah sindiran, kalimat perintah saran dan kalimat perintah bersyarat.Kalimat perintah berfungsi untuk menyuruh atau memerintah, meminta, mengajak, dan melarang agar lawan tutur melakukan sesuatu seperti yang diinginkan oleh penutur.

Kalimat perintah ditinjau dari isinya dapat dibedakan menjadi beberapa jenis, yaitu:

1. Perintah atau suruhan biasa, jika pembicara menyuruh lawan bicaranya berbuat sesuatu,

2. Perintah halus, jika pembicara tampaknya tidak memerintah lagi, tetapi menyuruh mencoba atau mempersilakan lawan bicara sudi berbuat sesuatu,

3. Permohonan, jika pembicara meminta lawan bicara berbuat sesuatu demi kepentingannya, 
4. Ajakan atau harapan, jika pembicara mengajak atau berharap lawan bicara berbuat sesuatu,

5. Larangan atau perintah negatif, jika pembicara menyuruh agar jangan melakukan sesuatu,

6. Pembiaran, jika pembicara meminta agar jangan dilarang.

Berdasarkan penjelasan di atas dapat disimpulkan bahwa kalimat perintah berfungsi untuk memerintah atau meminta kepada lawan tutur agar melakukan sesuatu seperti yang diinginkan oleh penutur.Dalam bentuk tulisannya, kalimat berita diakhiri dengan tanda titik (.) atau tanda seru (!).Bentuk kalimat perintah dapat dilihat pada contoh berikut.

'Jangan ramai-ramai Simbah sedang tidur.'

(d). Kalimat Seru (kalimat ekslamatif)

Kalimat seru atau dikenal juga dengan kalimat imperatif.kalimat ekslamatif yaitu kalimat yang isinya ungkapan rasa kagum atau heran atas sesuatu hal. Kalimat seru digunakan untuk mengungkapkan keheranan atau kekaguman atas hal tertentu.kalimat seruan digunakan untuk menyatakan emosi atau perasaan batin yang secara tiba-tiba. Misalnya, rasa terkejut, marah, kagum, gemas, kecewa, sedih cemas, takut, tidak suka, benci, iba, dan sebagainya.Kalimat seruan dibentuk dengan menggunakan kata seru, misalnya wah, cih, hai, o, oh, nah, ha, hah, aduh, celaka, ya ampun, kasihan, dan lain-lain.

Secara formal kalimat seru ditandai dengan kata 'alangkah, betapa, atau bukan main pada kalimat berpredikat adjektival'.Bentuk kalimat seru dapat dilihat pada contoh berikut.

"Wah, gedungnya bagus sekali, dalamnya seperti istana.',

g. Kalimat Imperatif

Menurut Windy Novia dalam kamus lengkap bahasa indonesia halaman 192 imperatif bersifat memberi komando bersifat memerintah, bersifat menguatkan, bentuk printah untuk kalimat yang mnyatakan larangan atau keharusan melaksanakan sesuatu. 
Menurut Abdul Chaer (2015 197) kalimat imperatif adalah kalimat yang meminta pendengar atau pembaca melakukan suatu tindakan. Kalimat imperatif dapat berupa kalimat perintah, kalimat himbauan, dan kalimat larangan.

Kalimat perintah mengharapkam adanya reaksi berupa tindakan fisik.Menurut sifatnya dapat dibedakan adanya kalimat perintah yang tegas, yang biasa, dan yang halus.

(1) Kalimat perintah yang tegas dibentuk dari sebuah klausa tidak lengkap, biasanya hanya berupa verba dasar, disertai dengan intnasi kalimat perintah.

Dalam Bahasa tulis intonasi ini diganti dengan tanda seru (!). contoh :

-Bersihkan!

-Tembak!

-Tulis!

Di sini verba itu dapat pula dilengkapi dengan objek atau keterangan agar tidak menimbulkan salah paham. Misalnya kalimat imperatif diatas menjadi :

-Bersihkan ruangan ini!

-Tembak kakinya!

-Tulis namamu disini!

Dalam sutuasi yang sudah diketahui akan apa yang harusdilakukan oleh pendengar, maka kalimat imperatif itu dapat berupa hanya menyebut nama orang yang diperintah. Umpamanya, situasi kurang ketika berlangsung pelajaran membaca di kelas, beberapa murid telah mendapatkan giliran membaca, maka kalua guru menyuruh murid yang bernama Sudin untuk membaca, maka kalimat perintah dapat hanya berupa:

-Sudin!

(2) Kalimat imperatif yang biasa dibentuk dari sebuah klausa berpredikat verba yang diberi partikel Lah, serta dengan menanggalkan subjeknya. Contoh Jagalah kebersihan!

-Bayarlah dengan uang pas!

-Belilah karcis di loket!

-Datanglah pada waktunya! 
-Tulislah dengan huruf kapital

Kalau orang yang perintah itu tertentu, maka subjek pada kalimat tersebut harus dtampilkan.Misalnya :

-Ali, jagalah kebersihan!

-Siti, rapikan dulu meja tulis itu!

-Ahmad, datanglah tepat waktu!

(3) Kalimat imperatif yang halus, sopan, dibentuk dengan menggunakan kata-kata tertentu yang menunjukan tingkat kespanannya. Kata-kata tertentu yang menunjukan tingkat kesopanannya. Kata-kata tersebut adalah mohon, harap, tlng, mintasilakan, sebaiknya, dan hendaknya. Contoh :

-Mohon agar surat-surat itu bapak tanda tangani dulu -Kami harap

Anda bisa memberi bantuan sekadarnya

-Tolong sampaikan salam kami kepadanya

-Saya minta agar saudara segera meninggalkan tempat ini

-Silakan mencicipi hidangan yang ala kadarnya ini -Sebaiknya

Anda menunggu sebentar disini

Hendaknya saudara berhati-hati kalua bicara disini

h. Wujud kalimat imperatif

Wujud imperatif adalah realisasi maksud imperatif dalam bahasa Jawa.Rahardi (2005: 88) menunjukkan ciri mendasar yang dimiliki satuan lingual dalam bahasa Jawa, yakni, (1) Kata kerja yang digunakan lazimya kata kerja dasar, (2) Mempergunakan partikel pengeras -lah 'lah'. Sedangkan penentu wujudnya adalah berbagai aspek bahasa, seperti: panjang pendeknya tuturan, pemakaian kata/frase satuan lingual penanda imperatif. Secara formal, tuturan imperatif meliputi dua macam wujud yaitu imperatif aktif dan imperatif pasif.

1) Imperatif Aktif

Imperatif aktif adalah realisasi terhadap bentuk imperatif yang verbanya aktif (Rahardi, 2005: 90). Imperatif aktif dalam bahasa Jawa pada penelitian ini dibedakan berdasarkan penggolongan verbanya menjadi dua macam, yakni imperatif aktif berciri tidak transitif dan imperatif aktif berciri transitif Rahardi (2005:88).

2) Imperatif Pasif 
Imperatif pasif adalah realisasi terhadap bentuk imperatif yang verbanya pasif (Rahardi, 2005: 90). Digunakan bentuk tuturan yang demikian karena padapemakaian imperatif pasif, suruhan yang dikandung di dalamnya cenderung menjadirendah. Bentuk imperatif pasif juga dapat mengandung konotasi makna bahwa orang ketigalah yang diminta melakukan sesuatu, bukan orang kedua.Permintaan dansuruhan yang terdapat di dalam imperatif itu tidak terlalu tinggi karena maksud tuturan itu tidak secara langsung tertuju kepada orang yang bersangkutan.Kepasifan tuturan imperatif adalah mengandung makna lebih formal dan lebih santun dibandingkan dengan tuturan imperatif yang tidak pasif.

Dengan demikian, dapat dikatakan bahwa di dalam pemakaian tuturan imperatif pasif itu terdapat maksud penyelamatan muka yang melibatkan muka si penutur maupun muka diri si mitra tutur.Penggunaan imperatif pasif bisa dilihat pada contoh di bawah ini.

Konteks: Tuturan 1 dan 2 dituturkan oleh seorang pimpinan kepada seorang sekretaris atau pembantunya. Tuturan (1) dituturkan dalam situasi yang agak tegang karena sang direktur marah, sedangkan tuturan (2) dituturkan dalam situasi yang lebih santai. Contoh :

Tuturan: 1 'Ketik surat itu dan kirim secepatnya!'

Tuturan : 2 'Surat itu diketik dan dikirim secepatnya!.'

\section{i. Makna kalimat imperatif}

Dalam KBBI (2001: 703), makna dijelaskan: makna 'arti': 'maksud', 'maksud pembicara atau penulis', pengertian yang diberikan pada suatu bentuk kebahasaan. Salah satu makna kalimat yang digunakan pada kalimat dalam bahasa Jawa adalah makna imperatif atau makna perintah. Berdasarkan maknanya aktivitas memerintah adalah praktik memberitahukan kepada mitra tutur bahwa penutur menghendaki orang yang diajak bertutur itu melakukan apa yang sedang diberitahukannya. Menurut Rahardi (2005: 93) makna imperatif adalah realisasi maksud imperatif menurut makna pragmatiknya, yakni apabila dikaitkan dengan konteks situasi tutur yang melatarbelakanginya munculnya tuturan imperatif itu.Makna tersebut sangat ditentukan konteksnya, baik konteks yang bersifat ekstralinguistik maupun intralinguistik. Konteks mencakup banyak hal, seperti lingkungan tutur, nada tutur, peserta tutur, dan aspek-aspek konteks situasi tutur lain. 
Dalam praktik komunikasi interpersonal atau komunikasi sehari-hari, sesungguhnya makna imperatif dalam bahasa Jawa tidak hanya diungkapkan dengan konstruksi imperatif atau pakon (suruh), melainkan juga dapat diungkapkan dengan konstruksi lainnya. Konstruksi lain yang dimaksud adalah konstruksi interogatif (pitakon atau pertanyaan) dan deklaratif (warta atau pernyataan). Jadi, dalam konteks situasi tutur tertentu, seorang penutur dapat menentukan apakah dalam bertutur ia harus menggunakan tuturan deklaratif dan interogatif untuk menyatakan makna.

\section{Metode Penelitian}

Jenis penelitian yang dilakukan dalam penelitian ini adalah menggunakan metode penelitian deskriptif kualitatif. Penelitian deskriptif kualitatif merupakan suatu penelitian yang datanya secara kualitatif dan penjabarannya secara deskriptif.

Menurut Sugiono (2019:18) metode penelitian kualitatif adalah metode penelitian yang berlandaskan pada filsafat postpositivisme, digunakan untuk meneliti pada kondisi obyek yang alamiah, (sebagai lawanya adalah eksperimen) dimana peneliti adalah sebagai instrumen kunci, Teknik pengumpulan data dilakukan secara gabungan, analisis data bersifat induktif/kualitatif, dan hasil penelitian kualitatif lebih menekankan makna.

\section{Tabel 1.1 Kisi-Kisi Instrumen Kalimat Imperatif Dalam Novel Selena Karya Tere Liye}

\begin{tabular}{|c|c|c|}
\hline No & Nilai yang & Indikator \\
\hline 1 & $\begin{array}{l}\text { Kalimat } \\
\text { Imperatif }\end{array}$ & $\begin{array}{l}\text { a. Kalimat imperatif permohonandalam novel selena } \\
\text { karya Tere Liye } \\
\text { b. Kalimat imperatif permintaan dalam novel selena } \\
\text { karya Tere Liye } \\
\text { c. Kalimat imperatif harapan dalam novel selena karya } \\
\text { Tere Liye } \\
\text { d. Kalimat imperatif larangan dalam novel selena karya } \\
\text { Tere Liye }\end{array}$ \\
\hline
\end{tabular}




\begin{tabular}{|l|l|l|}
\hline & $\begin{array}{l}\text { e. } \\
\text { Kalimat imperatif pembiaran dalam novel selena karya } \\
\text { Tere Liye }\end{array}$ \\
f. & Kalimat imperatif ajakan dalam novel selena karya \\
& Tere Liye \\
g. & Kalimat imperatif imbauan dalam novel selena karya \\
& Tere Liye
\end{tabular}

Tabel 1.2

Korpus Data Penelitian

\begin{tabular}{|c|c|c|c|}
\hline No & $\begin{array}{c}\text { Aspek Yang } \\
\text { Dia-nalisis }\end{array}$ & Indi-kator & $\begin{array}{c}\text { Deskripsi } \\
\text { Data }\end{array}$ \\
\hline 1 & $\begin{array}{l}\text { Kalimat } \\
\text { imperatif }\end{array}$ & $\begin{array}{l}\text { a. } \\
\text { imperatif } \\
\text { permohonan } \\
\text { dalam novel } \\
\text { selena karya } \\
\text { Tere Liye } \\
\text { Kalimat } \\
\text { imperatif } \\
\text { permintaan } \\
\text { dalam novel } \\
\text { selena karya } \\
\text { Tere Liye } \\
\text { Kalimat } \\
\text { imperatif harapan } \\
\text { dalam novel selena } \\
\text { karya } \\
\text { Tere Liye }\end{array}$ & $\begin{array}{l}\text { a. Ibu! Lihatlah, putrimu memiliki } \\
\text { Teknik bertarung yang hebat } \\
\text { sekali. ( halaman } \\
\text { :85 ) } \\
\text { b. "Tahan!” Aq memberi tahu } \\
\text { operator. ( halaman :29 ) } \\
\text { c. "Harap segera keluar!” tambah } \\
\text { yang lain. ( halaman :91 ) } \\
\text { d. "Nona, ini tempat terlarang!” } \\
\text { seru mereka. ( halaman :91 ) } \\
\text { e. "Bairkan semua ini terjadi } \\
\text { selena!” ( halaman :243 ) } \\
\text { f. “Ayo! Kalian kenapa diam } \\
\text { saja!” Aku berseru. "Bantu } \\
\text { Aku!" ( halaman :135 ) }\end{array}$ \\
\hline
\end{tabular}




\begin{tabular}{|l|l|l|l|}
\hline & $\begin{array}{l}\text { d. Kalimat } \\
\text { imperatif larangan }\end{array}$ & g. "Jangan biarkan mereka \\
& merusak formasi kita!" Tazk \\
& & \\
&
\end{tabular}




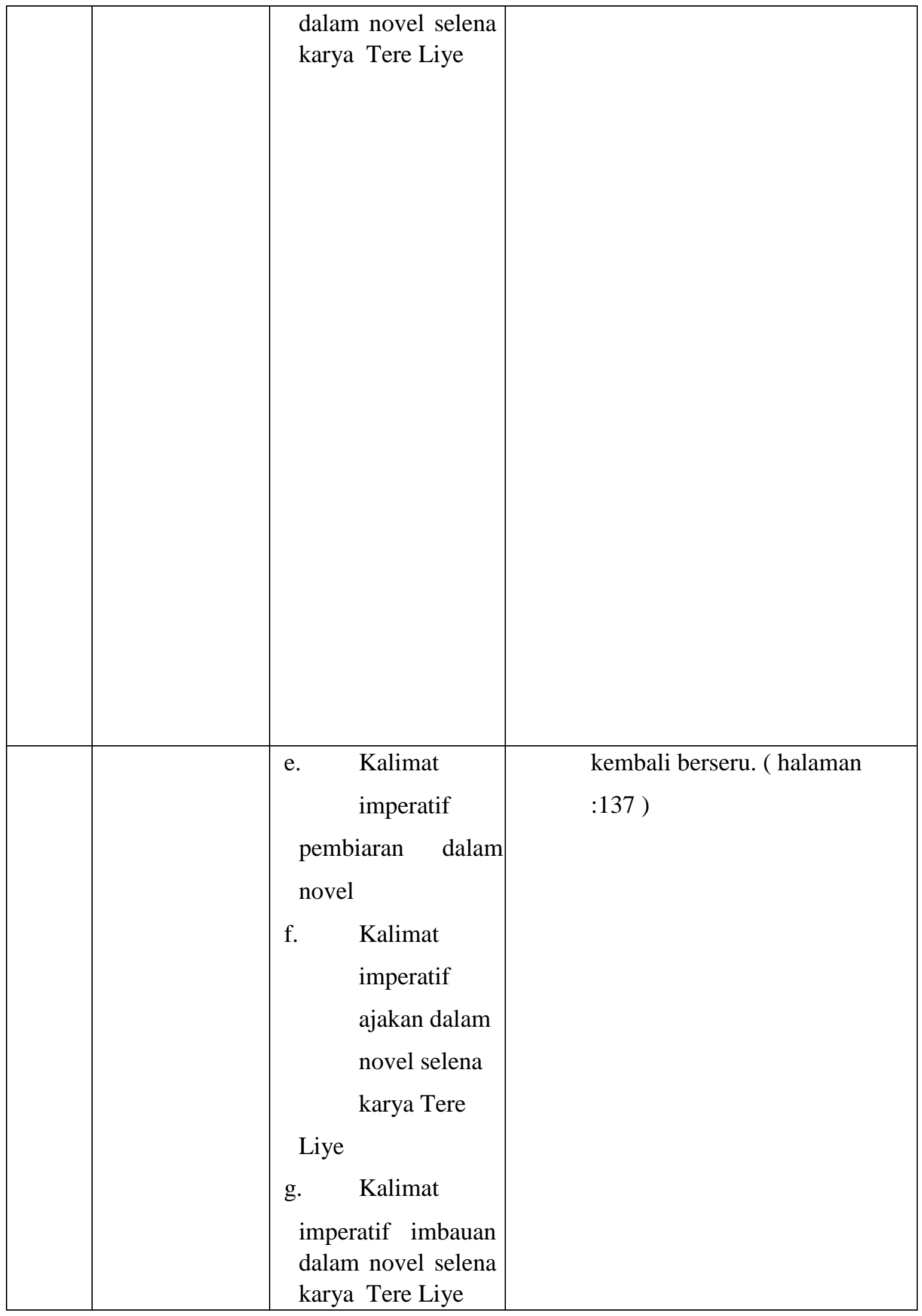




\section{Hasil dan Pembahasan}

Berdasarkan hasil penelitian yang berjudul kalimat imperatif dalam Novel selena karya Tere Liye menunjukkan bahwa kalimat imperatif digunakan di novel tersebut. Wujud kalimat imperatif yang terdiri dari kalimat imperatif biasa, kalimat imperatif permintaan, kalimat imperatif ajakan, kalimat imperatif suruhan dan kalimat imperatif larangan. Kalimat imperatif larangan yang ditandai dengan penanda kata jangan paling dominan digunakan dalam percakapan didalam novel tersebut.

Kalimat Imperatif Permohonan

Kalimat imperatif permohonan adalah bentuk kalimat perintah yang memakai kosakata halus seperti kata coba; silahkan; tolong; sudilah kiranya; dan sebagainya.

Kalimat Imperatif Permintaan

Kalimat imperatif permintaan adalah bentuk kalimat perintah yang menggunakan kata "minta" atau "mohon". Subjek dari kalimat imperatif permintaan tidak selalu dimunculkan dan biasanya subjek adalah penutur sendiri.

Kalimat Imperatif Harapan

Kalimat imperatif yang mempunyai makna harapan biasanya terdapat ungkapan penanda kesatuan "harap" dan "mugi-mugi”. Kedua kesatuan penanda diatas masing-masing mengandung makna harapan.

Kalimat Imperatif Larangan

Kalimat imperatif larangan adalah kalimat perintah yang didalamnya mengandung larangan dengan ditandai kata "jangan".

Kalimat Imperatif Pembiaran

Kalimat imperatif pembiaran adalah bentuk kalimat perintah yang didalamnya memuat kata biar; biarkan, lah.

Kalimat Imperatif Ajakan

Tuturan imperatif dengan makna mengajak dalam novel Selena karya Tere 
Liye bertujuan untuk mengekspresikan keinginan penutur agar mitra tutur untuk melakukan tindakan sama seperti penutur atau agar mitra tutur ikut serta dengan penutur.

\section{Kesimpulan}

Berdasarkan hasil penelitian dan pembahasan yang telah dideskripsikan, serta berdasarkan dengan rumusan masalah dan tujuan penelitian kalimat imperatif dalam novel selena karya Tere Liye dapat disimpulkan sebagai berikut.

Berdasarkan dari hasil penelitian penulis wujud kalimat imperatif yang terdapat dalam novel Selena karya Tere Liye adalah wujud imperatif intrasitif. Makna kalimat imperatif yang ditemukan berjumlah 7 makna yaitu makna imperatif permohonan, permintaan, harapan, larangan, pembiaran, ajakan, imbauan. Makna- makna tersebut muncul karena menyampaikan tuturan kepada mitra tutur yang terdapat dalam novel Selena karya Tere Liye tersebut bertujuan menimbulkan efek tindakan kepada mitra tutur.

\section{Daftar Pustaka}

Chaer Abdul. (2007). Linguistik Umum. Jakarta : Rineka Cipta.

Chaer, Abdul. (2012). Linguistik Umum. Jakarta: Rineka Cipta.

Emzir, 2018. Metodologi Penelitian Kualitatif Analisis Data. Depok: Rajawali Pers KBBI.(2020).Kamus Besar Bahasa Indnesia.(Online). Tersedia di Kbbi.Kemdikbud.Go.id. Diakses 4 juni 2020.

Kridalaksana, H. (2019). Kamus Linguistik. Jakarta: PT. Gramedia Pustaka Utama.

Mahsun. 2017. Metode Penelitian Bahasa: Tahapan,Strategi,Metode, Dan Tekniknya.Jakarta : PT. Rajagrafindo Persada.

Rahardi, R. Kunjana. (2005). Kesantunan Imperatif Bahasa Indonesia. Jakarta: Erlangga. 10.

Ramlan. (2005). Sintaksis. Yogyakarta: CV. Karyono Jl. Majen Sutoyo

Sugiono. (2019). Metode penelitian kuantitatif kualitatif dan R\&D. Bandung: Alfabeta Bandung.

Supri Yani Enita Eko, 2012. Kalimat Imperatif dalam Novel Emas Sumawur Ing Baluarti Karya Partini B. Universitas Negeri Yogyakarta.

Liye Tere. (2020). Selena.Jakarta: Gramedia Pustaka Agama.

Verhaar. 2012. Asas-asas Linguistik Umum. Yogyakarta : Universitas Gajah Mada Press. 
Jurnal PENEROKA Vol. 1, No. 01 (2021): Januari 2021 